\title{
Inpatients' satisfaction with food services in Sohag University Hospital
}

\author{
Mohamed A. Al-Torky*, Eman A. Mohamed*, Fouad MA.Yousef *, Nesreen \\ AM. Ali* \\ *Public Health, Faculty of Medicine, Sohag University \\ Received: July 2015, accepted: October2015
}

\begin{abstract}
Hospital food plays a significant role in the recovery and well-being of patients and helps them physically and emotionally during their hospital stay.Patient's opinion about hospital food is one of the main factors contributing to the success of hospital food services. Aim of the study: This study was conducted to determine inpatients' satisfaction with the provided food services in Sohag University Hospital. Subjects and methods: A cross sectional study was carried out for a period of 6 months (from March to August, 2014) in three major departments in Sohag University Hospital and it included 1015 inpatients. Interview questionnaire was used for collecting data about inpatients' general characteristics and evaluating inpatients satisfaction with food services. Results: Findings showed that $(60.8 \%)$ of the studied inpatients reported that they ate all hospital food or part of it. The rate of satisfaction with food services among them was $(64.2 \%)$. Age, educational level and department were significantly associated with the overall satisfaction level $(\mathrm{p}<0.05)$. Positive correlation was found between the overall satisfaction level and the different dimensions of food services. Linear regression of food services dimensions and overall satisfaction revealed that the food quality had the highest regression coefficient (0.69), which implies that food quality is significantly associated ( $\mathrm{p}<$ 0.05 ) with the overall satisfaction with food services provided for inpatients followed by staff/service issues, hot food factors, food quantity and physical environment. Conclusion: Improving different food services dimensions especially food quality enhances the level of overall satisfaction with hospital food services.
\end{abstract}

Keywords:Hospital Food Services, Patient Satisfaction, food quality, meal service quality

*corresponding author, Nesreen Hammad Email: nesreenhammad87@yahoo.com

\section{Introduction}

Health care establishments must assess and take patient satisfaction into consideration to remain viable ${ }^{(\mathbf{1})}$. Patients' satisfaction is the extent to which the patients feel that their needs and expectations are being met by the service provided ${ }^{(2)}$.

In addition, patients' satisfaction has become an essential issue by which the quality of health care services is evaluated and so,it is important to assess the effectiveness of any hospital service $\left.^{(3,}{ }^{4}\right)$.However, there is more emphasis on the quality of technical medical care in the local research in Egypt. Therefore, food services satisfaction may sometimes go unnoticed when looking at the overall hospital patient satisfaction.

On the other hand, findings of researches elsewhere reveal that food services quality is correlated with the overall hospital patient satisfaction (5), and it is necessary to assess patient views to make sure whether the food served meets the expectations of patients ${ }^{(6)}$. 
Catering services providers use patient satisfaction surveys to evaluate specific issues such as food quality, selection, service, and timing of serving the meal that could be improved (7) with more emphasis on patient care in an effort to enhance patient satisfaction and control costs ${ }^{(8)}$.

Monitoring patients' satisfaction with food services in the hospitals is one strategy to prevent malnutrition, as research clearly reveals that when patients' satisfaction with the food and food services declines, the risk for malnutrition increases ${ }^{(9)}$.

This study was conducted to determine inpatients' satisfaction with the provided food services in Sohag University Hospital.

\section{Subjects and Methods}

This study was conducted in the internal medicine, general surgery and obstetrics \& gynecology departments in Sohag University Hospital and included 1015 patients admitted to these departments. These departments are selected out of Sohag University Hospital departments as they are the major departments in the hospital. The three departments were reviewed twice weekly for a period of 6 months (from March to August, 2014). The admitted inpatients satisfying the following inclusion and exclusion criteria were interviewed and included in the study.

\section{$\underline{\text { Inclusion criteria }}$}

- Inpatient age is 18 years or older.

- Admission duration at the time of interview is not less than 3 days.

\section{Exclusion criteria:}

- Emergency cases.

- Patients receiving parenteral nutrition or on tube feeding.

- Patients who are fasting by doctors' instructions
- Patients who refuse to participate in the study.

- Patients who can't speak (mute) or listen (deaf).

- Patients having a mental health problem.

- Patients who are emotionally unstable.

\section{Data collection method}

Collecting inpatients' data and assessing their satisfaction with hospital food services was conducted through interviewing inpatients included in the study. The first part of the questionnaire was designed to collect data including sociodemographic data of the studied inpatients, duration of admission at the time of interview, whether nutritional advices related to their disease condition were given to them in the hospital or not, number of meals and whether they were satisfied by the timing of serving meals or not and getting food from outside the hospitals and reasons. The second part of the questionnaire, used a validated survey titled The Acute Care Hospital Food service Patient Satisfaction Questionnaire (ACHFPSQ) $)^{(\mathbf{1 0}, \mathbf{1 1})}$, to assess satisfaction of inpatients eating hospital food towards hospital food services. It is an accurate, reliable tool for measuring patient food services satisfaction. It differentiates food services into four main dimensions or categories, which include: food quality, meal service quality, staff/service issues, and physical environment. Moreover, other subcategories were included: meal size, hot foods, and hunger and food quantity.

\section{Data analysis and presentation:}

SPSS program version 16 was used for data entry and analysis. As regards The 
Acute Care Hospital Foodservice Patient Satisfaction Questionnaire (ACHFPSQ), each statement is rated on a scale from 'never' to 'always' and overall satisfaction with the food services was rated from 'very good' to 'very poor'. By the use of a five-point Likert scale, the responses were assigned a numeric value or score.

Correlation analysis was used to assess the association between overall satisfaction with the food services and different food service dimensions.

Multiple regression model analysis was conducted with overall satisfaction as response variable and different food service dimensions as the independent variables. The overall satisfaction variable was recoded where "very good", "good" and " okay" denotes that patient was satisfied while " poor" and "very poor" indicated that patient was not satisfied.

Chi-squared analysis was used to determine the effect of sociodemographic data, department, duration of hospital stay to survey date and prior hospitalization on overall satisfaction.

\section{Administrative design and ethical consideration}

Approval of the concerned administrative authority was secured and written informed consent after explaining the aim of the study was obtained from all inpatients who participated in the study. The questionnaires used in data collection were anonymous and confidentiality of data was assured.

\section{Results}

Table (1) presents socio-demographic variables, and general characteristics of the studied inpatients. Females comprised $(73.4 \%)$ of the respondents. Inpatients who were less than 30 years old represented $(26.1 \%)$ of the studied inpatients and those who were $\geq 50$ years old constituted more than one third $(35.5 \%)$ of them . About half of respondents $(49.9 \%)$ were illiterate, $(18 \%)$ had secondary education and higher education represented $(6.4 \%)$. In addition, (79\%) of them lived in rural areas and $(79.3 \%)$ were married. As regards the department of admission, (35.4\%) were admitted to the internal medicine department, $(29.5 \%)$ to general surgery department and $(35.1 \%)$ to obstetrics \& gynecology department. Regarding the length of stay, (74\%) of inpatients were admitted for more than five days at the time of interview. More than half of the respondents $(54.5 \%)$ were previously hospitalized.

Table (2) shows that $(84.3 \%)$ of the respondents reported that they receive 3 meals daily. More than two thirds of the respondents $(68.6 \%)$ were satisfied by meal serving time, $(26.1 \%)$ of them reported that they ate the entire amount served to them and $(34.7 \%)$ of them reported that they ate part of the served amount compared to (39.2\%) who didn't eat hospital food at all. All inpatients reported that they got food from outside the hospital. In addition, $(60.4 \%)$ reported that they weren't advised about appropriate diet for their health condition. None of the respondent inpatients reported that they have been asked about their preferred food.

Figure (1) describes the reasons reported by respondents for getting food from outside the hospital. More than fifth $(24.6 \%)$ of respondents reported that they felt hungry between meals, $(18.7 \%)$ reported that the amount of hospital food was inadequate, the unpalatable way of cooking was the reason why $16.3 \%$ of the studied inpatients got food from outside the hospital. Of the respondents $14.2 \%$ reported that they didn't like hospital food, $8.8 \%$ reported that hospital food was not suitable for their 
condition, and $6.6 \%$ wanted other food types.

Figure (2) represents responses of inpatients eating hospital food when they were asked to rate their satisfaction with hospital food services provided to them. The figure shows that $36.3 \%$ of participants rated their satisfaction as good while $30 \%$ of them rated it as poor. Only (5\%) of them reported that hospital food services were very good and $22.9 \%$ said that food services were okay. On the other hand, 5.8\% rated food services as very poor. The percentage of participants who rated their satisfaction as poor and very poor $35.8 \%$ was considered dissatisfied while higher ratings were considered satisfied $(64.2 \%)$.

Table (3) shows that age, educational level and department of admission had significantly affected the overall satisfaction of inpatients eating hospital food. Forty one percent of $(41 \%)$ satisfied inpatients with the provided food services were in the age group $\geq 50$ years while the age group $<30$ years represented only $(17.4 \%)$ of the satisfied group. High level educated inpatients represented only two percent of the satisfied group. On the other hand, illiterates represented $(63.6 \%)$. As regards the department of admission, $36.4 \%$ of the satisfied group were among inpatients admitted to general surgery department. On the other hand, there were no significant effect of gender, occupation, residence, marital status, length of hospital stay and prior hospitalization on inpatients satisfaction with food services.

As shown in table (4), there is a significant positive correlation between the score of overall satisfaction of inpatients and the scores of different categories of food services ( $p<0.001$ ). A significant strong positive correlation was found between food quality category $(\mathrm{r}=0.9, \mathrm{p}<0.001)$ and overall satisfaction scores. On the other hand, the lowest correlation was observed between physical environment category and overall satisfaction scores $(r=0.4)$. Table (5) illustrates the results of linear regression of food services categories and overall satisfaction. The food quality had the highest regression coefficient $(p<0.001)$, which implies that food quality is significantly associated with the overall satisfaction with food services provided for inpatients followed by staff/service issues, hot food, food quantity and physical environment.

\section{Discussion}

Considering patients' perception of hospital food services is necessary for the success of these services ${ }^{(5,12)}$. In addition, improved hospital food services can be achieved by identifying patients' expectations, needs and demands.

As regards timing of meals serving, $(31.4 \%)$ of the respondents were not satisfied by time of meals which is near the findings of Shreshtha M. et al., ${ }^{(13)}$ in a study conducted in India, where $(35 \%)$ of the studied patients were not satisfied by the time of serviceand the findings of Naithani S. et al., (14) in a study conducted in two London teaching hospitals to examine inpatients' experiences to access food sevices in hospitals where $(39.6 \%)$ of patients were not satisfied with serving times.In another study conducted by Elawadly M. et al., ${ }^{(15)}(50 \%)$ of the patients were not satisfied with time of meals serving.

Results revealed that (26.1\%)of respondents reported that they ate the entire amount served to them compared to $(39.2 \%)$ who didn't eat hospital food at all which is not in line with Sahin B. et al., ${ }^{(16)}$ who reported that only $(3.2 \%)$ of patients did never 
eat their food and in another study conducted by Hamilton K. et al., ${ }^{(17)}$ to examine the nutritional care of inpatients in Leicestershire Community Hospitals, (59\%) of the patients consumed all of their food.

In addition, findings of the present study is not in agreement with a study conducted in two Swiss hospitals by Stanga et al., ${ }^{(18)}$ where only (2\%) of the respondents ate no food.These differences may be attributed to more control on food transport, temperature and different portion sizes that were served and better food quality.

None of the respondents reported that they have been asked about their preferred food which is inconsistent with Donini et al., ${ }^{(\mathbf{1 9})}$ where the nursing staff tried to meet patients' preferences through the daily menu dishes or the available fixed alternative for each dish.

Thirty six percent of inpatients rated their satisfaction as good while $(30 \%)$ of them rated it as poor. Only (5\%) of them reported that hospital food services were very good.On the other hand, $(5.8 \%)$ rated food services as very poor. These findings were not in line with the findings of Ajaz M. et al., ${ }^{(20)}$ who conducted a study to evaluate patient satisfaction with the dietary services at Sheri Kashmir Institute of Medical Sciences Srinagar and reported that (69.9\%) rated dietary services as good, $(28.8 \%)$ as fair and only $(4.14 \%)$ as poor. These differences can be explained by better food quality, temperature, variety of the food served as reported by patients in the later study. In addition, these findings were not in agreement with a study conducted by Andrew F. et al., ${ }^{(11)}$ where (59\%) rated food services as very good, (28\%) reported that food was good, while those who rated food services as okay and poor comprmised (10\%) and (3\%) respectively and no patients reported that food services were very
poor.These differences may be explained, as the later study was conducted in a private hospital in Australia with more attention for services, quality monitoring and improvement.

As regards satisfaction with food services, $(64.2 \%)$ of the respondents eating hospital food were satisfied with hospital food services which is lower than findings reported byStanga et al., ${ }^{(18)}$ where $(86 \%)$ of respondents were satisfied or very satisfied with hospital food andthe findings of a study conducted by Abdel Hafez A. et al., ${ }^{(21)}$ in Makkah, Saudi Arabia, where $(78.8 \%)$ of patients were satisfied. This difference can be explained by better and more satisfactory aspects of food services reported by the studied patients. On the other hand,another study conducted by Emam $S$. et al., ${ }^{(22)}$ in Egypt, reported that patient satisfaction rate with hospital food was not high $(57.3 \%)$.

The current study revealed a significant difference $(\mathrm{P}<0.05)$ between satisfied and dissatisfied groups as regards age, educational level and department of admission which is inconsistent with Abdel Hafez A. et al., (21) where age, educational level and department of admission had no significant effect on satisfaction and with Sahin B. et al., ${ }^{(16)}$ whoreported that all demographic characteristics of patients were insignificant in explaining satisfaction level with food services.On the other hand, in a study conducted by Dube L. et al., ${ }^{(23)}$ individual characteristics such as age and education influenced patient satisfaction and in a study conducted by Wright $O$. et al., ${ }^{(24)}$ in nine residential aged care facilities in Brisbane, Australia,age had a significant effect on satisfaction with food services.

In addition, there was a significant positive correlation between the score 
of overall satisfaction of inpatients with the provided food services in the hospital and the scores of different categories of food services $(p<0.05)$. This is in agreement with the findings of Hwang Li-Jen J. et al., ${ }^{(25)}$ who observed a significant positive correlation between different aspects of food service, such as flavor, freshness and temperature of food, helpfulness of staff and environment, and level of patients satisfaction.In addition, these findings are in line with O'Hara P. et al., ${ }^{(\mathbf{1 2})}$ who reported that different aspects of food services were significantly correlated with the overall satisfaction.

As regards association between overall satisfaction and food services aspects, food quality was significantly associated with the overall satisfaction with food services provided for inpatients followed by staff/service issues, hot food, hunger \& food quantity, physical environment factors respectively and in a study conducted in Italy by Messina G. et al., ${ }^{(26)}$ the overall satisfaction was significantly associated with food quality, meal service quality, quantity and staff/service issues with the dimension that most influenced patients' overall satisfaction was food quality in both studies. Moreover, in a study conducted by Jessri M. et al., ${ }^{(27)}$ the main aspects which influenced patients' satisfaction included food quality, quantity, meal service and staff attitudes.In addition, in a study conducted by Abdel Hafez A. et al., ${ }^{(21)}$ the factors that were significantly associated with overall satisfaction included staff/service issues, taste of food and food temperature respectively.

\section{Conclusion}

Considering inpatients' preferences, perceptions, needs and complaints is essential to guarantee the provision of effective successful food services with high quality. Improving different food services dimensions especially food quality enhances the level of overall satisfaction with hospital food services.

\section{References}

1) Sheehan-Smith L. Key facilitators and best practices of hotel-style room service in hosptials. Journal of the American Dietetic Association. 2006; 106:581-6.

2) Ware J., Snyder M., Wright R. Defining and measuring patient satisfaction with medical care. Eval Prog Planning. 1983;6:247-63.

3) Tranter M., Gregoire M., Fullam F., Lafferty L. Can Patient-Written Comments Help Explain Patient Satisfaction with Food Quality? J Am Diet Assoc. 2009;109:2068-72.

4) Thind AH. Satisfaction with Care among Low-Income Women with Breast Cancer. Journal of Women's Health. 2010;19(1):77-86.

5) Aase S. Hospital foodservice and patient experience: What's new? J Am Diet Assoc. 2011;111(8):1118-23.

6) Ferguson M., Capra S., Bauer J., Banks M. Development of a patient satisfaction survey with inpatients clinical nutrition services. Australian Journal of Nutrition and Dietetics. 2001;58:157-63.

7) Boyce C., Neale P. Conducting InDeph Interviews: A Guide for Designing and Conducting In-Depth Interviews for Evaluation Input. Watertown, MA: Pathfinder International2006.

8) Buzalka M. You've tossed your trayline...now what? Food Management. 2008:pp.32-5.

9) Wright O., Connelly L., Capra S. Consumer evaluation of hospital foodservice quality: an empirical investigation. International Journal of Health Care Quality Assurance. 2006;19(2):181-94. 
10) Capra S., Wright O., Sardie M., Bauer J., Askew D. The acute hospital foodservice patient satisfaction questionnaire: the development of a valid and reliable tool to measure patient satisfaction with acute care hospital foodservices. Foodservice Res Int 2005;16:1-14.

12) O'Hara P., Harper D., Kangas M., Dubeau J., Borsutzky C., Lemire N. Taste, temperature, and presentation predict satisfaction with foodservices in a Canadian continuing-care hospital. J Am Diet Assoc. 1997;97(4):401-5. Epub 1997/04/01.

13) Shreshtha M., Vinti D. Assessment of Acceptability and Satisfaction of Patients for Government Hospital Diets. IOSR Journal of Nursing and Health Science. 2014;3(2):38-40.

14) Naithani S., Whelan K., Thomas J., Gulliford M.C., Morgan M. Hospital inpatients' experiences of access to food: a qualitative interview and observational study. Health Expectations. 2008;11(3):294-303.

15) Elawadly M., Radwan M., Tawfik A.A., Sabbour S.M. Assessment of the Quality of Nutritional Care of the Hospitalized Patients in Ain Shams University Hospitals. Faculty of Medicine: Ain Shams University; 2010.

16) Sahin B., Demir C., Celik Y., Teke K. Factors affecting satisfaction level with the food services in a military hospital. Journal of Medical Systems. 2006;30(5):381-7.

17) Hamilton K., Spalding D., Steele C., Waldron S. An audit of nutritional care delivered to elderly inpatients in community hospitals. J Hum NutrDiet. 2002;15(1):49-58.

18) Stanga Z., Zurfluh Y., Roselli M., Sterchi A.B., Tanner B., Knecht G. Hospital food: a survey of patients' perceptions. Clin Nutr. 2003;22(3):241-6. Epub 2003/05/27.
11) Andrew F., Stephen G., Mary H., Judith D.B. Use of the Acute Care Hospital Foodservice Patient Satisfaction Questionnaire to monitor trends in patient satisfaction with foodservice at an acute care private hospital. Nutrition \& Dietetics 2008;65:41-6.

19) Donini M., Castellaneta E., De Guglielmi S., De Felice R., Savina C., Coletti C., et al. Improvement in the quality of the catering service of a rehabilitation hospital. Clin Nutr. 2008;27(1):105-14.

20) Ajaz M., Haroon R., Dara S., Qadri G.J. Dietary Services viz-a-viz Patient Satisfaction at a Tertiary Care Hospital. JK-Practitioner. 2008;15(Suppl.2):S13-S5.

21) Abdel Hafez A., Al Qurashi L., Al Ziyadi R., Kuwair A., Shobki M., Mograbi H. Analysis of Factors Affecting the Satisfaction Levels of Patients Toward Food Services at General Hospitals in Makkah, Saudi Arabia. American Journal of Medicine and Medical Sciences. 2012;2(6):12330.

22) Emam S., Kamel E., Sadek R., El-Sherief, Khalifa M. Dietary Services in El-Minia University Hospital. MJMR. 2013;24(1):1 - 6.

23) Dube L., Trudeau E., Belanger M.C. Determining the complexity of patient satisfaction with foodservices. J Am Diet Assoc. 1994;94(4):394-8.

24) Wright O., Connelly L., Capra S., Hendrikz J. Determinants of foodservice satisfaction for patients in geriatrics/rehabilitation and residents in residential aged care. Health Expect. 2013;16(3):251-65.

25) Hwang Li-Jen J., Desombre T., Eves A. Gap analysis of patient meal service perceptions. International journal of health care quality assurance. 2003;16(3):143-53.

26) Messina G., Fenucci R., Vencia F., Niccolini F., Quercioli C., Nante N. Patients' evaluation of hospital 
foodservice quality in Italy: what do patients really value? Public Health Nutr 2012;16(4):730-7.

27) Jessri M., Mirmiran P., Johns N., Rashidkhani B., Amiri P., Azizi F. A qualitative difference. Patients' views of hospital food service in Iran. Appetite. 2011;57(2):530-3. 
Table (1): Criteria of studied population

\begin{tabular}{|c|c|c|}
\hline Variables & No. & Percentage $(\%)$ \\
\hline $\begin{array}{c}\text { Gender } \\
\text { male } \\
\text { female }\end{array}$ & $\begin{array}{l}270 \\
745\end{array}$ & $\begin{array}{l}26.6 \\
73.4\end{array}$ \\
\hline $\begin{array}{l}\text { Age ( years) } \\
<\text { 30 } \\
\text { 30- } \\
\mathbf{4 0 -} \\
\geq \mathbf{5 0}\end{array}$ & $\begin{array}{l}265 \\
203 \\
187 \\
360\end{array}$ & $\begin{array}{l}26.1 \\
20 \\
18.4 \\
35.5\end{array}$ \\
\hline $\begin{array}{l}\text { Educational level } \\
\text { illiterate } \\
\text { read \& write } \\
\text { primary } \\
\text { preparatory } \\
\text { secondary } \\
\text { higher education }\end{array}$ & $\begin{array}{l}506 \\
103 \\
74 \\
84 \\
183 \\
65\end{array}$ & $\begin{array}{l}49.9 \\
10.1 \\
7.3 \\
8.3 \\
18 \\
6.4\end{array}$ \\
\hline $\begin{array}{l}\text { Occupation } \\
\text { not working } \\
\text { manual worker } \\
\text { employed } \\
\end{array}$ & $\begin{array}{l}774 \\
171 \\
70 \\
\end{array}$ & $\begin{array}{l}76.3 \\
16.8 \\
6.9 \\
\end{array}$ \\
\hline $\begin{array}{l}\text { Residence } \\
\text { urban } \\
\text { rural }\end{array}$ & $\begin{array}{l}213 \\
802\end{array}$ & $\begin{array}{l}21 \\
79\end{array}$ \\
\hline $\begin{array}{l}\text { Marital status } \\
\text { single } \\
\text { married } \\
\text { divorced } \\
\text { widow }\end{array}$ & $\begin{array}{l}84 \\
805 \\
13 \\
113\end{array}$ & $\begin{array}{l}8.3 \\
79.3 \\
1.3 \\
11.1\end{array}$ \\
\hline $\begin{array}{l}\text { Department/ Ward } \\
\text { Internal medicine } \\
\text { General surgery } \\
\text { Obstetrics and gynecology }\end{array}$ & $\begin{array}{l}359 \\
300 \\
356\end{array}$ & $\begin{array}{l}35.4 \\
29.6 \\
35.1\end{array}$ \\
\hline $\begin{array}{l}\text { Duration of hospital stay to survey date } \\
\leq 4 \text { days } \\
\geq 5 \text { days }\end{array}$ & $\begin{array}{l}264 \\
751\end{array}$ & $\begin{array}{l}26 \\
74\end{array}$ \\
\hline Prior Hospitalization & 553 & 54.5 \\
\hline Total & 1015 & 100 \\
\hline
\end{tabular}


Table (2): Data related to meals provision and nutritional advice given to studied population

\begin{tabular}{|c|c|c|}
\hline Variable & No. & Percentage (\%) \\
\hline $\begin{array}{l}\text { Do you receive your } 3 \text { meals daily } \\
\text { Yes } \\
\text { No }\end{array}$ & $\begin{array}{l}856 \\
159\end{array}$ & $\begin{array}{l}84.3 \\
15.7\end{array}$ \\
\hline $\begin{array}{l}\text { Are you satisfied by the timing of each meal } \\
\text { Yes } \\
\text { No }\end{array}$ & $\begin{array}{l}696 \\
319\end{array}$ & $\begin{array}{l}68.6 \\
31.4\end{array}$ \\
\hline $\begin{array}{l}\text { What is the amount do you eat from served food } \\
\text { All of it } \\
\text { Part of it } \\
\text { Do not eat it }\end{array}$ & $\begin{array}{l}265 \\
352 \\
398\end{array}$ & $\begin{array}{l}26.1 \\
34.7 \\
39.2\end{array}$ \\
\hline $\begin{array}{l}\text { Do you receive advice about appropriate diet for your health } \\
\text { condition } \\
\text { Yes by dietitian } \\
\text { Yes by nurse } \\
\text { Yes by doctor } \\
\text { No } \\
\end{array}$ & $\begin{array}{l}0 \\
0 \\
402 \\
613\end{array}$ & $\begin{array}{l}0.0 \\
0.0 \\
39.6 \\
60.4\end{array}$ \\
\hline $\begin{array}{l}\text { Have you been asked about your preferred food } \\
\text { Yes by dietitian } \\
\text { Yes by nurse } \\
\text { Yes by doctor } \\
\text { No } \\
\end{array}$ & $\begin{array}{l}0 \\
0 \\
0 \\
1015 \\
\end{array}$ & $\begin{array}{l}0.0 \\
0.0 \\
0.0 \\
100\end{array}$ \\
\hline Total & 1015 & 100 \\
\hline
\end{tabular}

All in patients were getting food from out side 
Table (3): Comparison between satisfied inpatients and those who were not satisfied with food services.

\begin{tabular}{|c|c|c|c|}
\hline Variable & $\begin{array}{l}\text { Satisfied } \\
\text { No. }=396(64.2 \%)\end{array}$ & $\begin{array}{l}\text { Not satisfied } \\
\text { No. }=221(35.8 \%)\end{array}$ & P-value \\
\hline $\begin{array}{l}\text { Gender } \\
\text { Male } \\
\text { Female }\end{array}$ & $\begin{array}{l}96(24.2 \%) \\
300(75.8 \%)\end{array}$ & $\begin{array}{ll}58 & (26.2 \%) \\
163 & (73.8 \%)\end{array}$ & 0.63 \\
\hline $\begin{array}{c}\text { Age ( years) } \\
<\mathbf{3 0} \\
\text { 30- } \\
\mathbf{4 0 -} \\
\geq \mathbf{5 0} \\
\end{array}$ & $\begin{array}{ll}69 & (17.4 \%) \\
75 & (18.9 \%) \\
88 & (22.3 \%) \\
164 & (41.4 \%) \\
\end{array}$ & $\begin{array}{ll}57 & (25.8 \%) \\
57 & (25.8 \%) \\
40 & (18.1 \%) \\
67 & (30.3 \%) \\
\end{array}$ & 0.003 \\
\hline $\begin{array}{l}\text { Educational level } \\
\text { Illiterate } \\
\text { Read and write } \\
\text { Primary } \\
\text { Preparatory } \\
\text { Secondary } \\
\text { Higher education } \\
\end{array}$ & \begin{tabular}{|ll}
252 & $(63.6 \%)$ \\
34 & $(8.6 \%)$ \\
35 & $(8.8 \%)$ \\
21 & $(5.4 \%)$ \\
46 & $(11.6 \%)$ \\
8 & $(2 \%)$ \\
\end{tabular} & $\begin{array}{lc}101 & (45.7 \%) \\
24 & (10.9 \%) \\
12 & (5.4 \%) \\
23 & (10.4 \%) \\
46 & (20.8 \%) \\
15 & (6.8 \%) \\
\end{array}$ & $<0.001$ \\
\hline $\begin{array}{l}\text { Occupation } \\
\text { Not working } \\
\text { Manual worker } \\
\text { Employed } \\
\end{array}$ & $\begin{array}{l}320(80.8 \%) \\
61(15.4 \%) \\
15 \quad(3.8 \%) \\
\end{array}$ & $\begin{array}{lc}163 & (73.8 \%) \\
43 & (19.4 \%) \\
15 & (6.8 \%) \\
\end{array}$ & 0.09 \\
\hline $\begin{array}{l}\text { Residence } \\
\text { Urban } \\
\text { Rural }\end{array}$ & $\begin{array}{l}69(17.4 \%) \\
327(82.6 \%)\end{array}$ & $\begin{array}{l}45(20.4 \%) \\
176(79.6 \%)\end{array}$ & 0.38 \\
\hline $\begin{array}{l}\text { Marital status } \\
\text { Single } \\
\text { Married } \\
\text { Divorced } \\
\text { Widow } \\
\end{array}$ & $\begin{array}{l}29(7.3 \%) \\
309(78 \%) \\
6(1.6 \%) \\
52(13.1 \%)\end{array}$ & $\begin{array}{lr}19 & (8.6 \%) \\
175 & (79.2 \%) \\
4 \quad(1.8 \%) \\
23 & (10.4 \%)\end{array}$ & 0.74 \\
\hline $\begin{array}{l}\text { Department/ Ward } \\
\text { Internal medicine } \\
\text { General surgery } \\
\text { Obstetrics\& gynecology } \\
\end{array}$ & \begin{tabular}{|ll}
120 & $(30.3 \%)$ \\
144 & $(36.4 \%)$ \\
132 & $(33.3 \%)$ \\
\end{tabular} & $\begin{array}{ll}83 & (37.6 \%) \\
52 & (23.5 \%) \\
86 & (38.9 \%) \\
\end{array}$ & 0.004 \\
\hline $\begin{array}{l}\text { Duration of hospital stay to survey date } \\
\quad \leq 4 \text { days } \\
\geq 5 \text { days }\end{array}$ & $\begin{array}{ll}95 & (24 \%) \\
301 & (76 \%)\end{array}$ & $\begin{array}{l}59(26.7 \%) \\
162(73.3 \%)\end{array}$ & 0.46 \\
\hline Prior hospitalization & $220(55.6 \%)$ & $140(63.3 \%)$ & 0.06 \\
\hline
\end{tabular}


Table (4): Correlation between overall satisfaction scores and different aspects of hospital food services.

\begin{tabular}{||l||l||l||}
\hline Variables & Correlation coefficient $(\mathbf{r})$ & P - value \\
\hline Food quality & 0.9 & $<0.001$ \\
\hline Meal service quality & 0.6 & $<0.001$ \\
\hline Staff/service issues & 0.6 & $<0.001$ \\
\hline Physical environment & 0.4 & $<0.001$ \\
\hline Hot food & 0.7 & $<0.001$ \\
\hline Hunger \& food quantity & 0.5 & $<0.001$ \\
\hline
\end{tabular}

* Spearman correlation was used

Table (5): Final linear regression model showing the effect of food services aspect on the overall satisfaction.

\begin{tabular}{|l|l|l||}
\hline Food service aspect & Regression coefficient (CI) & P - value \\
\hline Food quality & $0.69(0.73-0.85)$ & $<0.001$ \\
\hline Staff/service issues & $0.12(0.08-0.17)$ & $<0.001$ \\
\hline Hot food & $0.11(0.05-0.14)$ & $<0.001$ \\
\hline Hunger \& food quantity & $0.07(0.02-0.09)$ & 0.001 \\
\hline Physical environment & $0.05(0.02-0.2)$ & 0.02 \\
\hline
\end{tabular}


Figure (1): The reasons reported by respondents for getting food from outside the hospital.

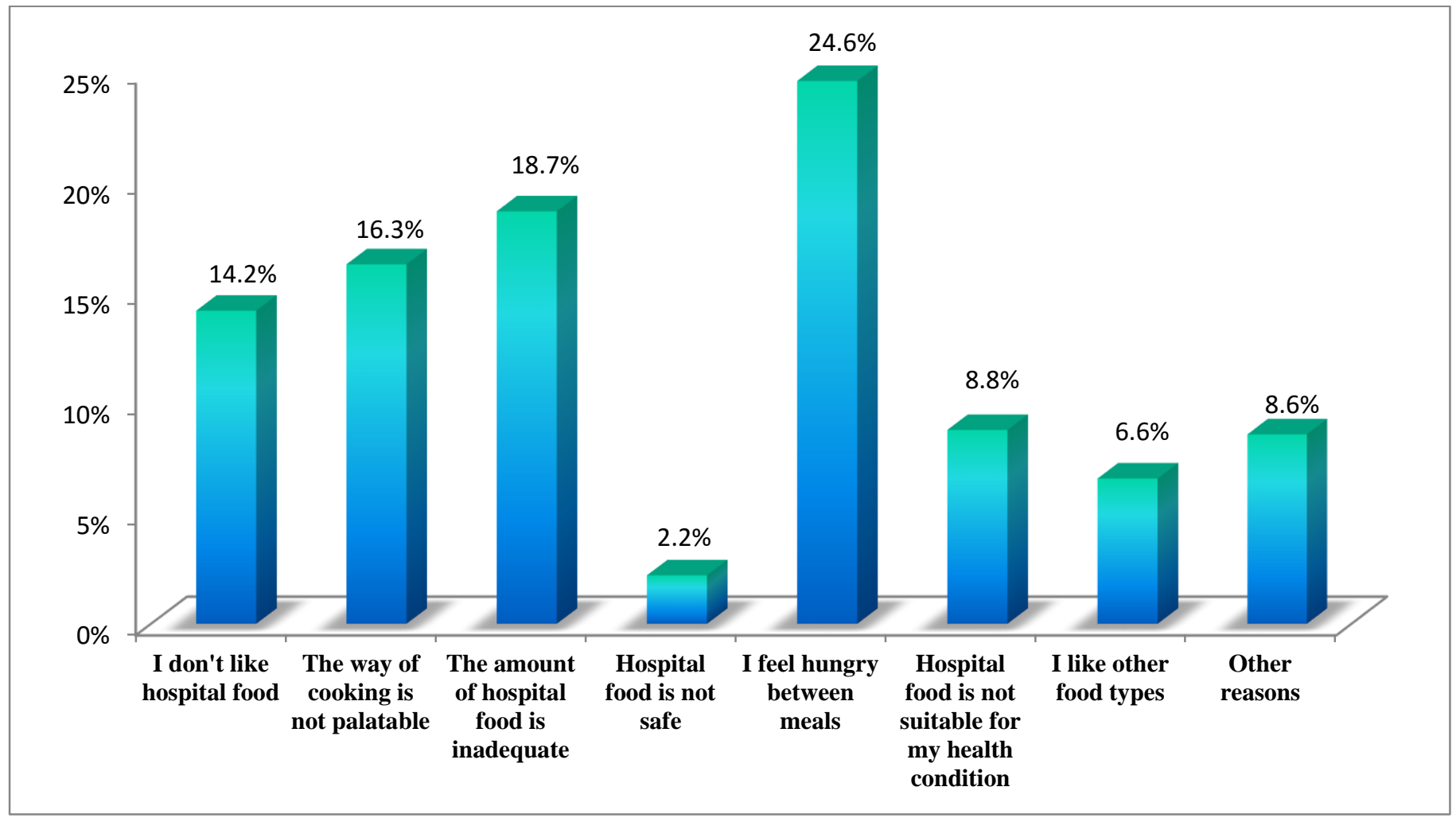

Figure (2): Degree of overall satisfaction of inpatients with hospital food services.

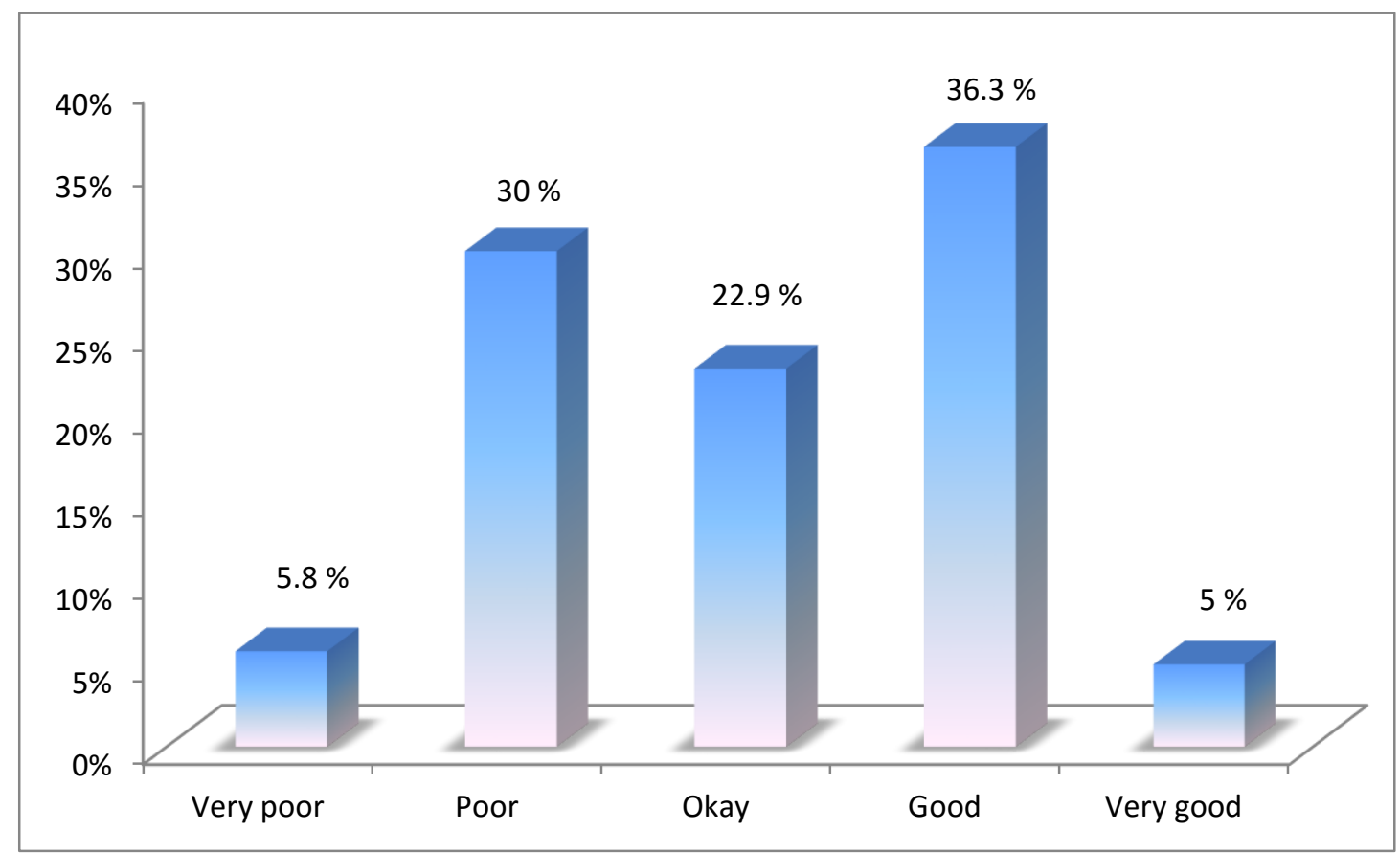

